\title{
マンション規模による物的特性と管理水準の相違 \\ 居住者による共同管理のためのマンション規模に関する研究 \\ A STUDY ON NUMBER OF UNITS OF CONDOMINIUM FOR MANAGEMENT OF LIVING ENVIRONMENT BY HOMEOWNERS' ASSOCIATION
}

\author{
齊藤広子* \\ Hiroko SAITO
}

\begin{abstract}
This study aims at examining a better supply, planning and management system of condominium. We clarified characteristics on managementlevel and problems by number of units and by scale of condominiums in the suburb of Tokyo Metropolis, Chiba-shi. The condominiums with small number of units, less than 50 units, have few common facilities and don't have fundamental system of management. The condominiums with medium number of units, from 100 to 200 units, have fundamental common facilities and a fundamental management system, which are relatively higher capabilities for management of living environment. The condominiums with large number of units, more than 200 units, have many and rich common facilities, high management-level, but they have difficulty to reach an agreement on management and reconstruction among the residents.
\end{abstract}

$\begin{array}{ll}\text { Keywords: } & \text { Condominium, Management, Living Environment, Homeowners' Association } \\ & \text { マンション }\end{array}$

1.はじめに 一研究の背景一

マンション (区分所有の共同住宅) は都市の主要な住宅形態とし て定着し、かつ都市の市街地形成やコミュニティ形成からみても重 要な構成要素となっている。マンションが良好に管理されないと、 マンション居住者の安定した居住が確保できないだけでなく、不良 ストック発生により様々な社会問題を引き起こし、都市景観、地域 コミュニティ、市街地形成などにも影響を与える。そのため、マン ションは私有財産の集合体であるが、適正な管理は社会的にも重要 な意味を持つ1)。

マンションの管理に都市形成やまちづくりの視点から注目すべ きことはそれではない。マンションには居住者による持続的に住環 境を管理する仕組みがある。つまり、現在、我が国の法や制度が設 定しているマンションの管理方法をみると、居住者全員が共同で管 理を行うことが原則となる ${ }^{2)}$ 。そのために、居住者全員による管理 の組織（管理組合）を結成し、必要なルール（管理規約）3）を居住 者によって決め、居住者はこのルールに従う。そして管理の最高責 任者（管理者）を決め、重要なことは居住者が全員参加できる集会 (総会) で決するざ)ことになる。このような体制の下で、共同で利 用する廊下や階段、設備、様々な施設を運営·維持管理するのである。 それを何十年もかけて継続し、計画的に行う必要があり、さらには
社会的状況や居住者の身体的条件にあわせてよりよいものへと空間 を改善する。また、管理組織が管理を行う対象は共用部分だけでは ない。居住者相互が快適な生活を送るために、所有権を制限するこ とにもなるが、各戸内である専有部分の生活や利用方法までもコン トロールできる仕組みを持つ。さらに公共性の高い共用空間の管理 や防犯・防災・福祉等のコミュニティ活動も居住者により行われる。 そこにはまさに居住者主体による物的環境(ハード)だけでなく非物 的環境(ソフト)も含めた持続的な住環境づくりがある。

しかし現実には居住者主体による持続的な住環境管理が全てのマ ンションで円滑に行われているとは言い難い。その理由は、居住者 が管理に無関心なことなどもあるが、居住者主体による管理が行い やすい条件が必ずしも整っていないことがある。このような条件は 入居後、居住者の手により整備することが可能なものもあるが、そ うでないものも多い。それは開発·計画時から考虑されるべきもので ある。だが、従来から、管理から開発や計画へのフィードバックが ほとんど行われず、住宅地・住宅の開発・計画において管理のしや すさがあまり考慮されてきていないのが現状である。

そこで、居住者により持続的に住環境の管理が行いや寸い条件を 整備するといった視点に立ち、マンションでどのような物的条件が 整えば管理が行いやすいのかを考察する必要がある。

\footnotetext{
$*$ 明海大学不動産学部不動産学科 助教授・学博

Assoc. Prof., Faculty of Real Estate Sciences, Meikai Univ., Ph. D.
} 


\section{2. 研究の位置つけと目的}

（1）居住者による共同管理のための目標水準（以下、管理水準）と その具体的指標の設定

居住者による持続的な住環境の共同管理の実践には第一に管理 体制の整備が必要となる。居住者が主体となり、居住者全員の意向 を踏まえ継続し計画的に管理を進める体制（管理組織、方針決定や 責任体制、計画・ルール、費用負担、支援体制）を整えることである。 具体的な指標として、管理組合の結成、総会の開催、管理者の選定、 管理規約の整備、理事会の開催、管理委託の状況、管理費の設定等 がある。

第二には、建物や共用施設・設備を適正に運営·維持管理し、長期 にわたり計画的に維持管理する体制の整備が必要である。その具体

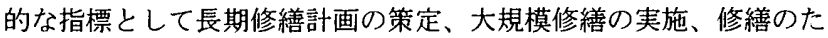
めの積立金の計画性、及び社会的水準や居住者の身体的条件にあわ せた改善の実施などがある。

第三には、居住者が相互に快適に生活をおくるためには各戸であ る専有部分の利用方法のコントロール体制の整備が必要である。そ の具体的な指標としてリフォームの仕方、事務所などの用途転用、 ペット飼育などの共同生活にかかわるルールの策定とルール遵守の ための活動などがある。

\section{（2）管理水準の規定要因と研究の目的}

上記に設定した管理水淮を規定する要因は既往研究によると、マ ンションの規模や、賃貸化や用途転用化、空き家化、高齢化などの 利用状況となる。これらの要因を物的特性に置き換えると、「規模 (住戸数)」「立地」「住戸専有面積」「築年数」となる。

本研究に先立ち、マンションの「立地」 ${ }^{5}$ 、「住戸専有面積」 ${ }^{6}$ 、

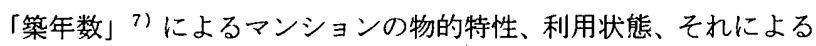
管理水準・管理問題の相違を明らかにした。しかし、「規模」に関し ては、小規模マンションでは管理水準が低く ${ }^{8)}$ 、大規模マンション では居住者の合意形成が困難になりやすいという指摘がある ${ }^{9)}$ が、 それがどの程度の規模であり、どのような点が異なるのかは明らか になっていない。

そこで本研究ではマンションの規模、それを示す指標として住戸 数に注目し、規模による物的特性、管理水準および管理問題の相違 を明らかにする。

\section{3. 研究の方法}

調查対象地区の選定：マンションが多く、大規模から小規模なマン ションがある地区として千葉市を取りあげる。千葉市は全世帯のう ち約 $1 / 7$ がマンションに居住し、マンションの管理水準が都市に与 える影響が大きい。

調查の方法 : (1).千葉市のマンションの物的特性を把握するために、 マンションリストを作成した。対象は築 5 年以上とし、319 マンシ ヨンを把握した ${ }^{10)}$ 。(2).マンションの規模により管理水準や管理問 題がどのように異なるかを把握するためのアンケート調查を管理組 合に直接配付・郵送回収方法で実施した。対象は築年数の違いが反 映しにくく、かつ管理水準の相違が明らかになるように築 20 年以 上のマンションに限定した。調查は 1998 年 11 月と 1999 年 11 月 ２000 年 1 月に実施し、配付数 111 、回収数 77 である。(3)上記の マンションについて 1 団地認定と公道の状態を市の資料で把握した。

\section{4. マンション規模による物的特性の相遣}

マンション規模によりどのように物的特性が異なるかをみる。マ ンション規模として住戸数を見ると、最も少ない場合は 8 戸、多い 場合は 1530 戸と幅広く、平均が 154 戸である。千葉市のマンショ ンは古いものに規模の大きいものが多い。築 30 年以上の場合は平 均 640 戸、築 20 年 29 年で平均 231 戸である (図 1 )。

住戸数が多くなると棟数も多くなる（図2）。1 棟（単棟）型は 約 6 割で、その他は複数棟（団地）型となり、最も多いものが 41 棟である。単棟型マンションのうち最も住戸数が多い場合は 282 戸 で、200 戸を超えると 9 割が団地型、300 戸を超えるとすべてが団 地型である。

建物高さとして階数をみると、規模の大きいものは築年数が経っ ているものが多いため中層（5階まで）が多いが、他に比べ、高層 の比率も高い(図 3 )。

敷地の広さは住戸数が多くなるほど大きくなるが（図 4)、なか でも規模の大きい古いマンションでは容積率も低く、オープンスペ ースが多い。

立地を見ると、交通の便に関しては、50 戸未満の小規模マンシ ヨンはバス便が少なく、駅から徒歩圈が多く、用途地域も近隣商業 地区や商業地区が多い。

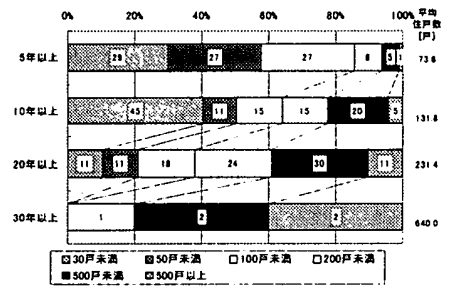

图1. 丞年数別マンション規模(住戸数)

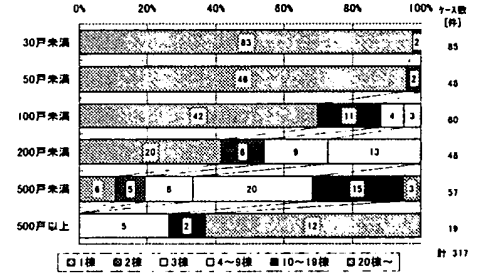

図 2. 住戸数別にみたマンションの楝数

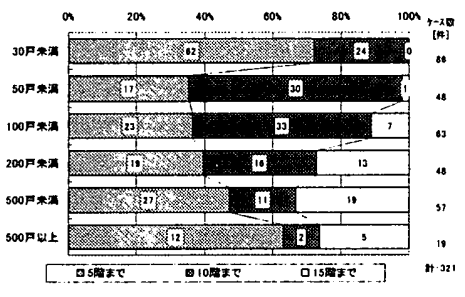

因 3. 住戸数別にみた階数

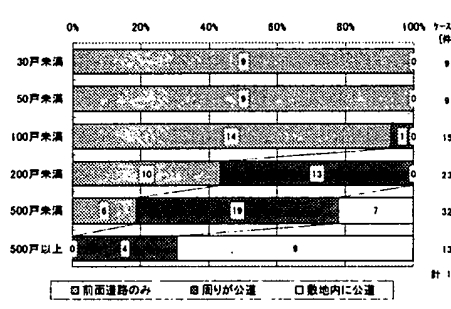

图 5. 住戸数別にみた公道の状態 一築 20 年以上一

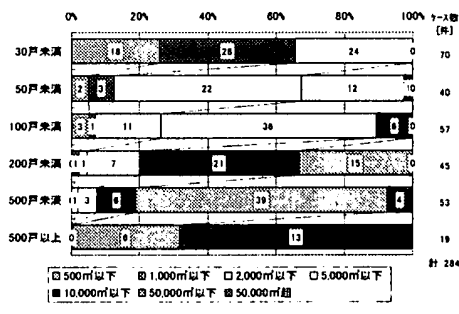

图 4. 住戸数別にみた數地面皘
規模が大きくなると敷地内に公道が含まれることが多い(図 5 )。 団地型マンションでは、1/3 が公道により敷地が分割されている。 また、規模が大きくなるほど 1 団地認定によるものが多く、その約 半数が他団地や賃貸を含めるなどの形での 1 団地認定である ${ }^{11}$ (図6)。 
5. 共用施設の整備の状態一築 20 年以上マンションー

共用施設の整備状態はマンション規模による違いが大きい（表 1)。管理人室・管理事務室は 50 戸未満のマンションでは約半数と 少ないが、100戸以上になるとほぼ整備される ${ }^{12)}$ 。集会所も 100 戸 未満では少ないが、100 戸以上になると 9 割以上にある ${ }^{13)}$ 。自転車 置き場の整備は規模にかかわりない14)。しかし、バイク置き場にな ると 100 戸を超えないと整備率は低い。駐車場に関しては規模にか かわらす整備率は高いが、戸あたり整備率をみると、規模の大きい ものほど整備率が高い 15)。また来客用駐車場の整備も規模の大きい 場合 (200戸以上) で多い。

他に子供の遊び場や公園、緑地といったオープンスペースは規模 が大きいほど整備率が高まり 16)、200 戸を超える規模の大きいとこ ろでは井戸、グランド、テニスコート、プールなどがみられる。エ レベーターなどの設備は規模による違いは殆どない。

\section{表 1. 住戸数別共用施設の整備状況}

\begin{tabular}{|c|c|c|c|c|c|c|c|c|c|}
\hline 別 & 管理人 & & 自転車 & 置丰場 & ハイク & 置奉場 & 駐百 & 官埸 & \\
\hline & 室 & 臸 & & 醋 & & 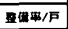 & & 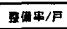 & $x$ \\
\hline 50戸未渾 & 55.6 & 11.1 & 88.9 & 96.8 & 44.4 & 12.6 & 100.0 & 23.7 & 9 \\
\hline 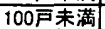 & 76.9 & 5.4 & 84.6 & 61.4 & 38.5 & 10.7 & 84.6 & 36.3 & 13 \\
\hline 200戸未满 & 100.0 & 92.9 & 100.0 & 139.1 & 78.6 & 25.7 & 92.9 & 60.3 & 14 \\
\hline 500戸末满 & 100.0 & 92.0 & 91.7 & 106.5 & 91.7 & 13.0 & 95.8 & 67.3 & 25 \\
\hline 500 户以上 & 93.3 & 100.0 & 93.3 & 74.6 & 93.3 & 7.7 & 100.0 & 68.2 & 16 \\
\hline 全体鳌備萃 & 89.3 & 72.0 & 92.0 & 74.7 & 74.7 & 14.7 & 94.7 & 65.3 & 77 \\
\hline 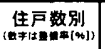 & $\begin{array}{l}\text { 来客用 } \\
\text { 駐車場 }\end{array}$ & \begin{tabular}{|l|} 
子供の \\
遊び埸
\end{tabular} & 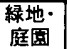 & $\begin{array}{l}\text { 共同 } \\
\text { 井市 }\end{array}$ & $\begin{array}{c}\text { ら゙ラン } \\
\text { ド }\end{array}$ & $\begin{array}{l}\bar{\sigma}=\pi \\
\lrcorner=r\end{array}$ & プール & IL & $\begin{array}{l}r- \\
2 \times \\
\end{array}$ \\
\hline 50戸未渾 & 11.1 & 11.1 & 22.2 & 0.0 & 0.0 & 0.0 & 0.0 & 44.4 & 9 \\
\hline 100戸未渾 & 15.4 & 15.4 & 38.5 & 7.7 & 0.0 & 0.0 & 0.0 & 69.2 & 13 \\
\hline 200戸末淽 & 57.1 & 50.0 & 50.0 & 0.0 & 0.0 & 0.0 & 0.0 & 42.9 & 14 \\
\hline 500戸未満 & 75.0 & 83.3 & 87.5 & 12.5 & 8.3 & 8.3 & 12.5 & 50.0 & 25 \\
\hline 500戸以上 & 80.0 & 100.0 & 93.3 & 46.7 & 13.3 & 39.3 & 6.7 & 25.0 & 16 \\
\hline 全体整備壈 & 54.7 & 60.0 & 65.3 & 14.7 & 5.3 & 10.6 & 5.3 & 46.7 & 77 \\
\hline
\end{tabular}

以上のように 50 戸未満のマンションでは共同管理の拠点となる 管理(人) 室の整備が少なく、100 戸末満では管理のための集会施設 の整備が少ない。100 戸を超えると基本的な施設が整い、200 戸を 超えると管理のための施設が整備され、かつ豊かなオープンスペー ス、来客用の駐車場等も整備される。このように規模の小さいマン ションでは管理のために必要な施設等の共用スペースは少なく、必 要な施設を外部依存している。一方、規模の大きなマンションでは 豊かな共用スペースをもち、それらの公開性が高く、良好な住環境 を外部提供している。

\section{6. 規模による管理水準の相違一築 20 年以上マンションー}

\section{(1)・管理組合の運営体制}

管理体制として「管理組合がない」17)のは2マンションである。 マンション規模は 15 戸と 52 戸の場合である。管理規約の整備状態 をみると、どのマンションでも規約はある。しかし、20 年以上一度 も改正したことがない18) マンションは規模が小さいほど多い（図 7 )。200戸を超えたマンションでは 9割以上のマンションで管理規 約の改正を行っている。管理の最高責任者である管理者をみると(図 8)、区分所有者 (居住者) の代表である理事長としているマンショ ンは規模の大きいマンションである。100１99 戸のマンションで 約 8 割、200 戸〜499 戸のマンションで約 9 割、500 戸以上のマン ションですべて理事長としている。運営管理の重要な役割を果たす 理事会は、規模が大きくなるほど定期的に開かれる（図 9)。200

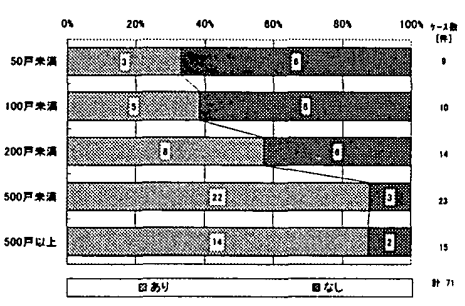

図 7. 住戸数別にみた管理規約の改正

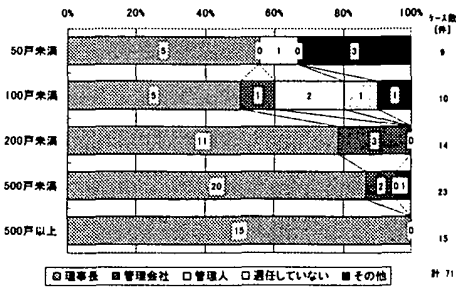

图 8. 住戸数別にみた管理者

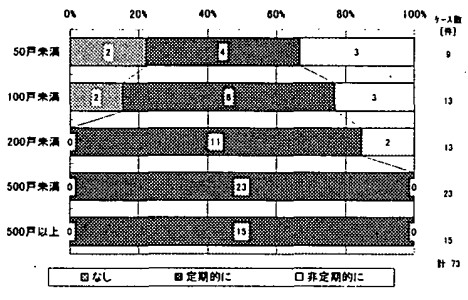

図 9. 住戸数別にみた理事会の開催

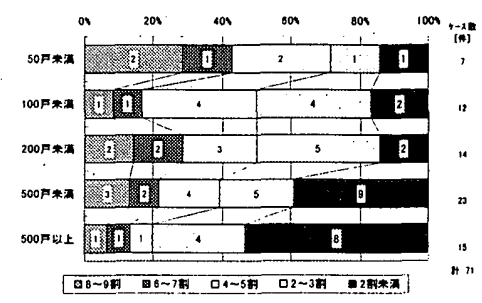

图 10. 住戸数別にみた総会の出席状況

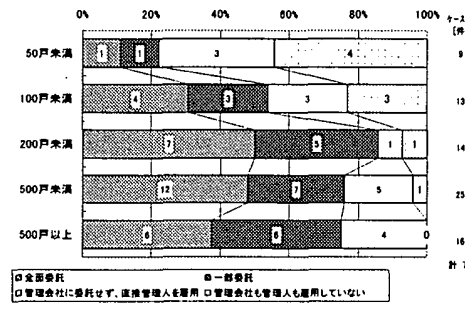

図 11. 住戸数別にみた管理形態

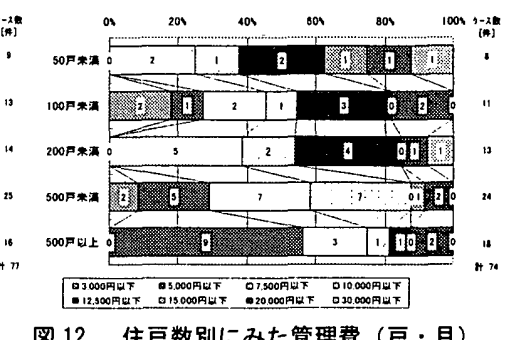

戸以上のマンションであればすべてで定期的に開かれる。しかし規 模が大きいマンションでは居住者が全貣参加し、管理の重要な方針 を決める総会の出席率が低くなる。50戸を超え、規模が大きいほど、 居住者の出席率は低くなる傾向がある（図 10）19）。

居住者による管理を支える仕組み（支援体制）として、管理会社・ 管理人の雇用状況（管理形態）をみる。100 戸を超えたマンション では管理会社への委託、管理人の常駐率が高い（図 11）。50 戸未満 のマンションでは管理会社も管理人も雇用していないケースが約半 数である。次に以上の仕組みを維持する費用をみると、50戸未満の マンションでは管理会社や管理人を雇用していないにもかかわらず、 管理費が全体的に高い(図 12)。規模が大きくなるほど管理費は低く なる傾向がある。

（2）長期的な維持管理の体制

築 20 年以上のマンシ ヨンでは大規模修綣はど のマンションでも実施さ れているが、小規模マン ションでは「いつ実施し たかわからないケケース がやや多い。これは計画 的に修繥を実施していな いためである。そこで長

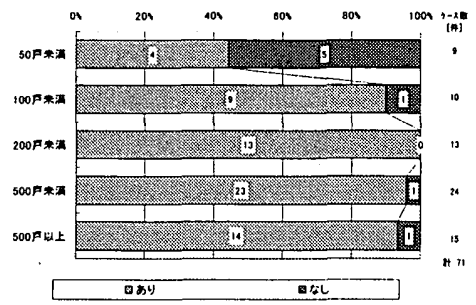

図 13. 住戸数別にみた長期修繥計画の策定
期修繒計画の策定状況をみると、策定していないマソションは 50 戸未満の小規模マンションでは半数以上である（図 13）。そのため 修縜積立金を長期修縜計画に基づいて積み立てている率も約 4 割と 
低い(図 14)。50９9 戸、100～199 戸のマンションでは 6〜 7 割

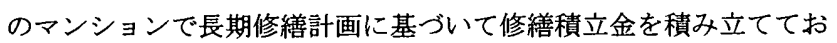
り、200 戸以上のマンションになると、ほぼす心゙てのマンションで 計画に基づいて積み立てている。

その状況をみるために 1 ケ月の戸当り修繥積立 金額をみる。修縵に必要 な費用は建物の形態、築 年数、施工の状態、建物 の痛みの状態などにより 異なるが、概ね規模の効 果が働くと考えられる。 1 つの目安として住宅金 融公庫の優良中古マンシ ヨン維持管理基隻 (築 20 年以上マンションの修䌡 積立金額）の「 1 万円」 でみると、概ね 1 万円積 み立てているマンション は小規模マンションでは なく、200〜499 戸のマ

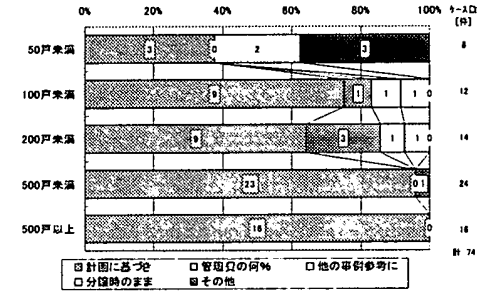

图 14. 住戸数別にみた修結䅪立金の算出根挟

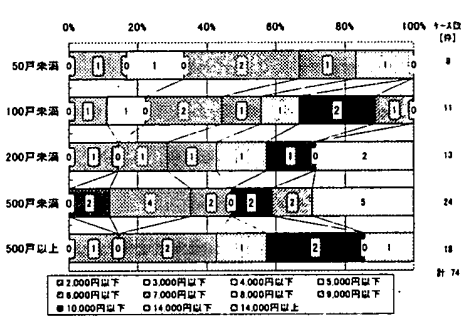

图 15. 住戸数別にみた修鉝稆立金（戸・月） ンションでは約 4 割と多い（図 15）。規模が大きいマンションの 方が規模の効果が働き、積み立て金額が低いわけではない。これ は計画に基づいて必要金額を積み立てているからと考えられる。 一方、小規模マンションでは計画に基づいて必要な金額が積み立 てられていないことから金額が低いものが多い。

次に居住者が自分たちの居住の場をどのように住み心地のよ いものに改善しているか、その実施状況をみる（表 2)。駐輪所や駐 車場の増設、共用部分に手すりやスロープの設置、外壁の色の変更、 集会所の増築などがみられる。集会所の増築は規模の大きいマンシ ヨンで多い。しかしすべての改善行為が規模の大きいマンションほ ど多いわけではない。100〜199 戸のマンションで実施率が最も高 く、200〜499 戸のマンションではやや下がり、500 戸以上のマン ションでは項目によっては高くなる。これは、改善は共用部分の変 更及び費用負担があることから必ず居住者の合意形成が必要となり、 住戸数により費用負担金額及び居住者の意見のまとめやすさが異な るからである。戸数が少ないと改善のために負担する戸当り金額は 高くなるが、人数が少ないことから比較的意見がまとめやすい。一 方、戸数が多いと戸当り負担金額は低くなるが、人数が多くなり意 見がまとめにくい。そのため、規模が大きい場合には低額で誰にで もメリットがあるような改善は行いやすいが、負担金額が大きかっ たり、立場によって意見が異なりやすいものには合意形成がしにく くなる 20)。

\begin{tabular}{|c|c|c|c|c|c|}
\hline 改善実施 & 50戸末海 & 100戸末酒 & 200户末满 & 500戸丰渵 & 500戸以上 \\
\hline 共用部分の階段に手すりを & $0.0 \%$ & $30.8 \%$ & $35.7 \%$ & $24.0 \%$ & $37.5 \%$ \\
\hline 段差のあるところにスローブをつけた & $0.0 \%$ & $23.1 \%$ & $57.1 \%$ & $20.0 \%$ & $43.8 \%$ \\
\hline エレベーターを増設・設置した & $0.0 \%$ & $0.0 \%$ & $7.1 \%$ & $0.0 \%$ & $0.0 \%$ \\
\hline 防犯カメラ・オートロックを設置した & $22.2 \%$ & $23.1 \%$ & $50.0 \%$ & $20.0 \%$ & $25.0 \%$ \\
\hline 駐車場を設置喵毃した & $33.3 \%$ & $46.2 \%$ & $100.0 \%$ & $40.0 \%$ & $87.5 \%$ \\
\hline 駐輪場を設置·增設した & $44.4 \%$ & $69.2 \%$ & $78.6 \%$ & $36.0 \%$ & $81.3 \%$ \\
\hline 菓会所·集会至を钤置·増殷した & $11.1 \%$ & $15.4 \%$ & $28.6 \%$ & $32.0 \%$ & $31.3 \%$ \\
\hline 外壁の色を変立た・タイルにした & $0.0 \%$ & $46.2 \%$ & 42.9\% & $12.0 \%$ & $37.5 \%$ \\
\hline 广一ス数 & $\overline{9}$ & 13 & 14 & 25 & 16 \\
\hline
\end{tabular}

\section{（3）各住戸の利用の仕方のコントロール}

マンションは集合住宅であることから、共同生活に関するトラブ ルが多い。そのなかでも、ペット飼育や騒音などのトラブルが多い。 ペット飼育については「禁止」や「条件付き」の対応が取られるが、 特に500戸を超える大規模マンションでは居住者の意向を踏まえて 「条件」を決めることが難しく「禁止」が多い。上下階の騒音トラ ブルにも影響を与える、リフォームへの対応は大規模なマンション では特に取り組みがない。住戸を貸貸にすることについては小規模 マンションで「条件付」にしていることが多い。事務所などに利用 する用途転用は全体的に「禁止」が多いが、大規模マンションほど 「禁止」の率が高い。
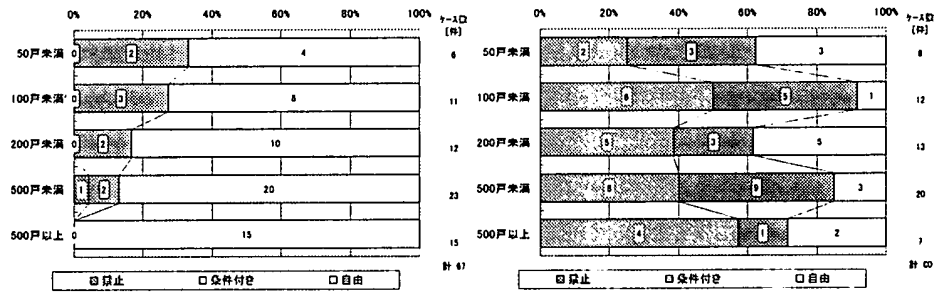

图 16. 住戸数別にみた賈貸化の凡ーれ 图 17. 住戸数別にみたペットの飼育ルーれ

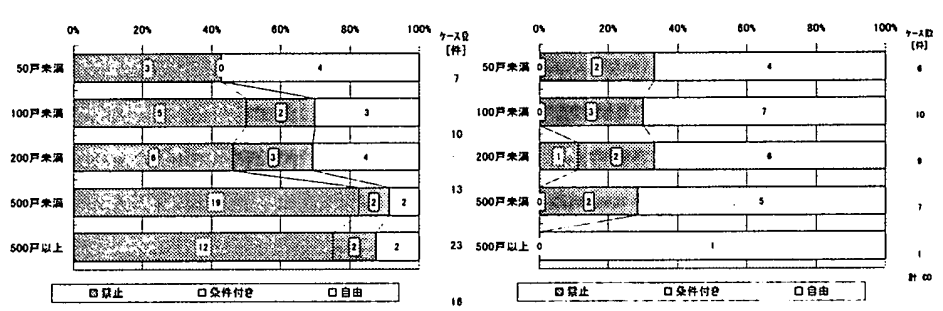

图 18. 住戸数別にみた用途転用のれーれ 图 19. 住戸数別にみたリーフォームのルーれ

このように小規模マンションではお互いの生活や利用の仕方に よる影響が大きいことから、どのような利用形態であってもできる だけルールを決めて対応しようとする。一方、大規模マンションで は用途転用禁止のように居住者の合意を取りやすいものはルールを 決め、その他はあまりルールを設けないか、「禁止」が多い。

ルール違反者への対応は、 50 戸未満のマンションでは組織的に注 意し、個人の自覚をうながすなどきめこまやかな対応がみられるが、 500 戸以上のマンションでは組織的な対忘が多い（表 3 ）。

\section{7. 規模による管理問題の相違一築 20 年以上マンションー}

小規模マンションでは管理組合からみて管理費が高いこと、管理 費の滞納の問題、計画修繮に関することなど、管理体制の基本的な 体制を整えることが問題となっている。中規模マンションでは駐車 場や駐輪所の不足といった共用施設の整備·運営にかかわる問題が 多くなる。大規模マンションになると基本的な体制が整い、それら

\section{表 3. ルール取締り状況}

生活トラブルへの対応

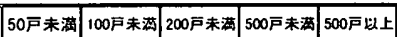

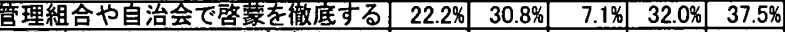

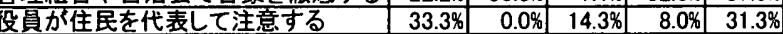
\begin{tabular}{|l|l|l|l|l|l|}
\hline 鿓がついた人が注意する & $33.3 \%$ & $0.0 \%$ & $14.3 \%$ & $8.0 \%$ & $31.3 \%$ \\
\hline
\end{tabular} \begin{tabular}{|r|r|r|r|r|}
\hline $0.0 \%$ & $0.0 \%$ & $14.3 \%$ & $0.0 \%$ & $0.0 \%$ \\
\hline
\end{tabular} 周りの人がしづらい算囲気にする \begin{tabular}{|l|r|r|r|r|r|}
\hline 個入が自覚を持つようにする & $55.6 \%$ & $23.1 \%$ & $35.7 \%$ & $12.0 \%$ & $18.8 \%$ \\
\hline その他 & $0.0 \%$ & $7.7 \%$ & $0.0 \%$ & $8.0 \%$ & $12.5 \%$ \\
\hline
\end{tabular} 
の問題は少なくなるが、共用施設の整備·運営の問題や、建替えへの 取り組みもみられ、建替えが円滑に進められないことが問題となっ ている(表 4)。このように管理組合からみた管理問題は、分譲会社・ 管理会社·管理人などの外部との対立・トラブルと、管理組合内部の 調整困難による問題があるが、規模が大きくなると内部調整の問題 が多くなり、特に空間整備の居住者間の合意形成が困難になってい る。

表 4. 住戸数別管理問題 (問題ありと回答した比率\%・複数回答)

\begin{tabular}{|c|c|c|c|c|c|c|c|c|c|c|c|}
\hline & 满司 & 满 & $\begin{array}{c}200 \text { 戸 } \\
\text { 未洴 }\end{array}$ & $\begin{array}{l}\text { 500户 } \\
\text { 夫满 }\end{array}$ & $50 \overline{7}$ & & 渵 & $\begin{array}{l}\text { 100” } \\
\text { 夫满 }\end{array}$ & 工 & & \\
\hline & 1.1 & 8 & 0.0 & 20 & 18.8 & & 1.1 & $0 . c$ & 7.1 & 0.0 & 12. \\
\hline 且合 & 0.0 & 7.7 & 7.1 & 4.0 & 12.5 & & 55. & 15. & 14.3 & 8.0 & 6. \\
\hline 西理 & 11.1 & 23.1 & 0.0 & 4.0 & 12.5 & $5 z \sigma$ & 0.0 & 0. & 7.1 & 0.0 & 6. \\
\hline 笋理会 & 0.0 & 77 & 7.1 & 4.0 & 6.3 & 3改萻 & 0.0 & 0. & 0.0 & 4.0 & 0. \\
\hline 再人 & 11.1 & 7.7 & 14.3 & 4.0 & 12.5 & 5 & 11.1 & 0. & 7.1 & 0.0 & 25 \\
\hline 除 & 11.1 & 0.0 & 0.0 & 4.0 & 6.3 & 3 & 11.1 & 30.8 & 78.6 & 32.0 & 37. \\
\hline 䝷理費など & 22.2 & 7.7 & 0.0 & 0.0 & 6.3 & 3 駐輪 & 11.1 & 23.1 & 35.7 & 12.0 & 12. \\
\hline & & & & & & & & & & & \\
\hline
\end{tabular}

\section{8. 大規模マンションの空間初期設定による管理への影響}

規模が大きくなると、複数棟になり団地型マンションが多くなる こと、建物の階数が高くなり、高層・超高層が多くなる。今回の調 查対象マンションは築 20 年以上であることから、高層・超高層マ ンションが少ない。そこでここでは、規模が大きくなる問題として、 マンションの複数棟化（団地型マンション）の問題を取りあげる。

(1)住戸尃有面積の多梾性：1 マンション内の住戸専有面積に幅があ ると、それにより居住者層・利用形態が多様になり合意形成が困難 になりやすい。さらには空間整備の費用負担は住戸専有面積に応じ 一ることが多いため、住戸専有面積の幅により費用負担金額に幅がで き、より一層合意形成を困難にする。団地型マンションで最大住戸 面積と最小住戸面積にほとんど違いがない場合が約 2 割、 $20 \mathrm{~m}^{2}$ 未満 の違いあるも のが約 6 割、 $20 \mathrm{~m}^{2}$ 以上の 差がある場合 が約 2 割と幅 がある（図

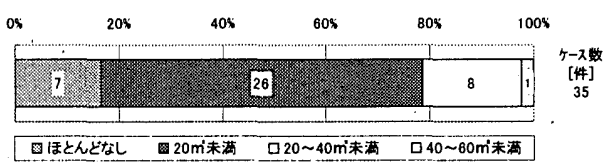

20)。

(2)棟による物的特性の相違 :「複数棟」ある場合には棟による物的 特性の相違が棟別管理要求の相違を生み出し、合意形成を困難にす る。

$$
\text { 第一には }
$$

棟による形態

や施工などの

物的特性の相

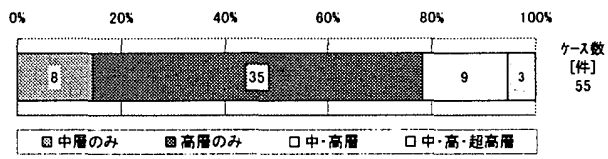

違が合意形

成・費用負担を複雑にする。例えば、高さの違い、それによるエレ ベーター等の設備の違い、外壁の仕上げ材の違い、施工会社や施工 時期の違いにより、必要な修繥費用に相違が生じる。団地型マンシ ョンで中層と高層、中層・高層・超高層の混成が約 2 割ある(図 21)。 第二には、棟による住戸数の違いが合意形成・費用負担の決め方 を複雑にする ${ }^{21)}$ 。棟別住戸数をみると、棟による違いがほとんどな
いものから、

最高 50 倍の

差があるもの

まで幅広い

(図 22)。

第三には、

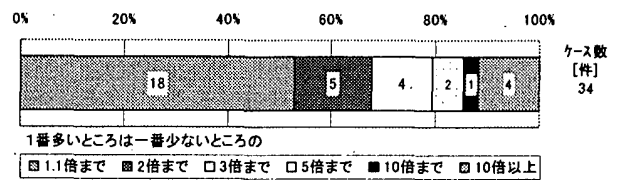

22. 1マンション内の住戸数の遟い

共用施設の配置が全棟に均等に配置されず、棟による利便性の不平 等が大きい場合は共用施設運営の合意形成·費用負担が複雑になる 22)。

(3)所有形態の設定 : 上記のような複雑な空間形態に所有形態も複雑 なことが多い。第一には、住戸専有面積に応じた敷地面積の持ち分 が設定されていないことがある。第二には、全体所有と棟別所有が あり、特定棟に全体で利用する集会所や駐車場が整備されているこ とがある。

(4)共同管理への影響 : 複数棟のマンションの場合には、1 つのマン ションをいくつかの管理単位に分けて管理したり、団地全体の管理 と棟単位の管 理と段階をも つことが考え られる ${ }^{23) 。 ~}$

しかし実

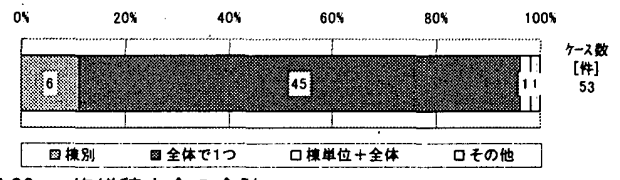
图 23. 修繒積立金の会部

際の管理組合の構成は「全体で1つの管理組合」が多く、「棟レベル の組合十団地レベルの組合」「棟レベルの組合のみ」「複数棟ごとに 組合」が1 ケースづつであり、団地全体を一つの管理組合で統一管 理している場合が多い。維持管理については、修繵費の会計をみる と、「棟別会計」を行っているケースが約 2 割あるが、「全体で $1 つ$ の会計」が約 8 割と多い（図 23）。以上のように、規模が大きいマ ンションでも、運営管理・維持管理面ともに、管理単位をわけたり、 棟別にするなどせず、マンション全体を一つとした管理単位をとつ ている。それは棟別などの管理がしやすいように利用を考慮した空 間構成・所有形態が設定されていないからである。そのため、修䜌 費や管理費の負担、建替えについて「棟間の調整」「棟と全体の調整」 のあり方が問題となっている ${ }^{2+)}$ 。

\section{9. まとめ}

千葉市のマンションを取り上げ、居住者による共同管理のための マンションの適正規模を考察するため、マンション規模（住戸数） による物的特性、管理水準と管理問題の相違を明らかにした。

100 戸まで、特に 50 戸までの小規模マンションでは共用施設が あまりなく、管理システムが確立しておらず場当たり的な運営とそ れによる維持管理が行われやすく、管理の費用も高い。しかし、生 活管理面に関しては「顔がみえる範囲」の対応が可能となる。

100〜199 戸までのマンションは基本的な共用施設が整い、居住 者の意見がまとめやすく、費用的にも管理人や管理会社への委託も 可能となり、管理システムの基本的なことは整っている。

200 戸を超え、特に 500 戸を超え大規模になると、団地型が多 く、豊かな共用部分を持ち、管理会社や管理人への委託が高くない 管理費の負担が可能となり、管理規約・理事会など居住者による民 主的でかつ計画的・継続的な管理システムが確立している。しかし、 一方では、居住者の総会の出席率が低い上うに管理への関心も低く 
なり、居住者お互いの顔もみえにくくなり、生活管理面へのきめこ まかな対応も難しく、空間整備においても合意形成が困難になりや すい。また、団地型マンションでは、所有に応じた全体の管理（団 地管理）と棟別管理の管理体制が必要となるが、団地全体の統一管 理の体制をとることが多く、実態として棟別及び棟間調整を含んだ 管理システムは現在あまり整備されていない。今後マンションの築 年数が経つほど修縡の必要な個所・費用が増加することが予想され、 かつ建替えも考虑すると、問題が生じてくることが考えられる。そ のため、所有関係や利用関係を詳細に把握した上で、規模が大きい、 団地型マンションの管理システムを確立する必要がある。

以上のように規模の小さいマンションでは共用施設の地域依存 型が多く、管理体制が整備されにくいことから、地域マンションの ネットワーク化により、規模の少なさをカバーできる管理システム が必要になる。居住者の合意形成を考慮すると 50 戸から 200 戸程度 までのマンションが望ましいと考えられる。それ以上大きなマンシ ヨンではこの単位がいくつか集まり、全体として豊かな共用空間を むつ団地を形成する形態が考えられる。その際、棟レベルと全体レ ベルの空間構成・所有形態の計画・設定は、管理面を考慮して行う 必要がある。

碀辞 : 本研究を進めるにあたり調查には川瀬明美氏（当時明海大学大学院生 西戸啓陽氏（当時東京電機大学学生・現明海大学不動産学部助手）の協力を 得た。マンションの管理組合の皆様には調查にご協力いただきました。ここ に記して関係者皆样に感謝の意を表します。

\section{注}

1) マンション管理が適正に行われないことによる地域に与える影響として、 たとえば、(1)自転車置き場や駐車場の不足による道への溢れ出しなど共用施 設の不適切な整備·運営による地域への影響、(2)建物の劣化による都市景䚇一 の影響やコンクリート落下による危険性の向上、(3)空家の増加による地域の 人口堿少と都市経営への影響、(4)管理放畗したマンションに浮浪者がすみつ くなど地域治安への影響などがある。これらの外部不経済を予防・解消する ためにマンション管理に行政の関与が一定みられる。さらに 2001 年 8 月に国 土交通大臣により公表されたマンションの管理の適正化に関する指針ではマ ンションは社会的資産として位圈付けられている。

2) 建物の区分所有等に関する法律（区分所有法）第 3 条では区分所有者全貝 による管理組合は当然存在するとしている。尚、法で管理組合の構成員とし ているのは区分所有者であるが、居住用マンションでは概ね区分所有者自ら が居住者であることから、本文では特に単密に区分所有者という必要がある ところ以外は「居住者」とする。

3）管理規約はマンションの所有・利用の権利に大きく関わることから、その 設定·変更・廃止には $3 / 4$ 以上の多数による決議が必要になる。

1)必ず集会で決するべき事項（特別決議事項）には、共用部分の変更、共有 敷地·付属施設の変更、規約の設定·変更·廃止、管理組合の法人化、団地規約 の承認、建替えなどがある。

5) 立地の違いに注目し、都心型として新宿区、郊外型として千葉市のマンシ ヨンを取り上げ、マンションの規模（住戸数）や形態、共用施設の整備状態、 住戸專有面積、用途転用や賃貸等の利用形態・居住者層が異なること、それ による管理水淮や管理問題の相違を明らかにした（参考文献 1)。

6) マンションの専有住戸面積から分類したワンルームタイプ、ファミリータ イプ、混在タイプでは、住戸の用途転用や货貸等の利用形態・居住者層が大 きく異なり、管理水準・管理問題が異なる(参考文献 2)。

7)築後年数を経たマンションでは高齢化や荏贷・空き家率が高まり、かつ 維持管理の必要な個所や费用、改善の必要性が高まり、管理上の課題や困難 性が高まる(参考文献 $3 \sim 7$ 等)。

8) 小規模マンションの管理問題の指摘は参考文献 8 などがある。
9) 模模が大きい場合、管理や建替の合意形成が困難になる(参考文献 9 等)。

10) 千葉市住宅政策課が所有していたリスト(高層住宅協会作成のリストをべ 一スに管理組合連絡協議会等の资料も参考に作成）と不動産経済研究所・C $\mathrm{R} I$ 作成のマンションリストをあわせ、住宅地図で所在を確認し棟数・前面 道路幅を、都市計画図で用途地域・指定容積率などを把握した。

11) 1 団地認定や公道の状態は日常管理には特に影響はないが、改善や建替え 時には制約となる。

12) 東京圈 1 都 3 県 249 市町村の宅地開発・建築指導要網のうち、集合住宅 を対象とするのは 92 自治体である (1997 年)。集合住宅で管理人室設置の規 定があるのは 17 で、内容は概ね 50 戸以上の場合は管理人を常駐とし、管理 人室を設貫することとしている。尚、千䒩市には現在規定がない

13）千葉市では 200 戸以上の場合に集会所を設けるようにしている。

14) 千葉市では現在の指導要網では $130 \%$ 整備することになっている。

15) 駐車場は現在の指導要綱では $60 \%$ 整備することになっている。

${ }^{16)} 0.3 \mathrm{~h}$ a 以上の開発は $3 \%$ を公園に、緑地は $10 \%$ 以上整備することになっ ている。

17) 区分所有法では存在することになるが、実質的に存在していない。

18) 管理規約の改正が必要となる外的要因として昭和 58 年の区分所有法の改 正、57 年の標準管理規約の設定と平成 9 年の改正がある。これを契機に 20 年間に一度も改正していないということは分譲会社が用意した規約のままで あり、規約が実質的に機能していないことも考えられる。

19）一般的に規模が大きくなると管理への関心が低くなる。そのため、一部の マンションでは総会までに棟ごとに棟集会を開くなどの工夫がある。

20) 例えば駐車場增設に関しては総論としては賛成であるが、増設位圈につい ては自分の棟の前にできることは反対といった、位置などによる立場の違い が意見の相違をつくりやすい。

${ }^{21}$ 棟每に利害関係が大きく異なるときに、棟による戸数の違いが決議に大き な影響を及活すことになる。

22) 例えば、ある棟のなかに全体の共用部分である集会所や駐車場が含まれて いる場合に利用の優先度や棟別修綧費用の負担が問題となる。

23) 区分所有法や標準管理規約では、団地レベルと棟レベルそれぞれに集会、 管理者、管理規約をもつことが想定されている。

24) ここであげられた他にも、開発時に開発業者が地方自治体や地域住民とむ 寸んだ協定により入居後居住者の管理負担が高いこと、公開性・公共性の高 い共用空間の管理負担が高いこと、表示登記がなかなかできないこと、建替 えの際に全体と棟別の決議をどのようにとるのかなど、樣々な問題がある。

\section{参考文献}

1）齊藤広子他；マンション建替えにおける管理組合の合意形成能力 1999.11、都市計画別冊 平成 11 年度都市計画論文集 No. 34 p. $307 \sim$ p. 312

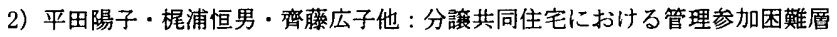
に関する研究、1989.11、日本建築学会計画系論文報告集第 405 号 p. 129 $\sim$ p. 140

3）松本恭治他：同潤会アパートの老朽化と維持管理・更新に対する居住者意 識について その 1 3 $1976 \cdot 1977.1978$ 日本建築学会大会梗概集

4）松本恭治他；分変集合住宅の欠宿と老朽化 その 1 3 1979 日本建築 学会大会梗概集

5）山本育三他：経年的にみた公団分諼集合住宅の維持管理に関する研究 そ の 1 3 1982 日本建築学会大会梗概集

6）藤木良明他 ; 分培集合住宅の耐久性回復に関する研究 その $1 \sim 101988$ ～1997 日本建築学会大会梗概集

7）齊藤広子他：築 27 年のマンションにおける居住者と所有者の状態からみ た管理上の課題 一マンションの住環境向上型メンテナンスの研究 $(7)$

日本建築学会東海支部研究報告集 1996. p. 777 p. 780

8）笠原秀樹：管理·建替えの規定要因と相互関係、『マンションの增築・建替 之』 1991 清文社 p. $98 \sim$ p. 128

9）齊藤広子・長谷川洋；マンション建替えの初動期の合意形成過程とその課 題 2001.5 日本建築学会計画系論文集第 543 号 p.239 245

(2001年 4 月19日原稿受理, 2001 年11月21日採用決定) 